\title{
Effect of Super-Oxidized Water, Sodium Hypochlorite and EDTA on Dentin Microhardness
}

\author{
Alexandre Corrêa Ghisi ${ }^{1}$, Patrícia Maria Poli Kopper², Flávia E. R. Baldasso² \\ Caroline P. Stürmer' , Giampiero Rossi-Fedele ${ }^{3,4}$, Liviu Steier ${ }^{3}$, José Antonio \\ Poli de Figueiredo ${ }^{1}$, Renata Dornelles Morgental ${ }^{1,5}$, Fabiana Vieira Vier- \\ Pelisser $^{1}$
}

The present study aimed to evaluate the influence of the following irrigating solutions on the microhardness of root canal dentin: $2 \%$ sodium hypochlorite $(2 \mathrm{NaOCI}), 5 \%$ sodium hypochlorite $(5 \mathrm{NaOCI})$, super-oxidized water (400 ppm Sterilox - Sx) and 17\% EDTA (E). Eighty roots from bovine incisors were randomly divided into 8 groups $(n=10): 2 \mathrm{NaOCl}$, $5 \mathrm{NaOCl}, \mathrm{Sx}$, and $2 \mathrm{NaOCl}+\mathrm{E}, 5 \mathrm{NaOCl}+\mathrm{E}, \mathrm{Sx}+\mathrm{E}$ (associated with $\mathrm{E}$ as final irrigant for 5 $\mathrm{min})$, E solely and distilled water ( $\left.\mathrm{dH}_{2} \mathrm{O}\right)$ as the negative control. Root canal preparation was performed by hand instruments, using one of the irrigation protocols for $30 \mathrm{~min}$. Then, $5 \mathrm{~mm}$ of the cervical root third were cut out from each sample and subjected to the Vickers microhardness test, at two points, one at approximately 500-1000 $\mu \mathrm{m}$ from the root canal lumen (distance 1), and the other at approximately 500-1000 $\mu \mathrm{m}$ from the external root surface (distance 2). Data were analyzed by Wilcoxon and Kruskal-Wallis tests at 5\% significance level. Microhardness values at distance 1 were significantly lower than those at distance 2 for all groups, except $5 \mathrm{NaOCl}$ and $5 \mathrm{NaOCl}+\mathrm{E}$ groups ( $p>0.05)$. EDTA showed the lowest microhardness values. However, no statistically significant difference was detected among groups at distance 1 and EDTA was significantly different only from Sx at distance 2 . In conclusion, all tested solutions showed lower microhardness at the most superficial root canal dentin layer compared to the one found near the external root surface, except $5 \mathrm{NaOCl}$ and $5 \mathrm{NaOCl}+\mathrm{E}$; EDTA promoted lower microhardness values in comparison to Sterilox at this site.

\author{
'Department of Endodontics, School \\ of Dentistry, PUCRS - Pontifical \\ Catholic University of Rio Grande \\ do Sul, Porto Alegre, Brazil \\ ${ }^{2}$ Department of Conservative \\ Dentistry, School of Dentistry, \\ UFRGS -Federal University of Rio \\ Grande do Sul, Porto Alegre, Brazil \\ ${ }^{3}$ Department of Endodontics, \\ Dentistry, Warwick Medical School, \\ Warwick, United Kingdom \\ ${ }^{4}$ Department of Endodontics, School \\ of Dentistry The University of \\ Adelaide, South Australia, Australia \\ ${ }^{5}$ Department of Endodontics, \\ School of Dentistry, UFPEL - Federal \\ University of Pelotas, Pelotas, Brazil
}

Correspondence: Profa. Dra. Renata Dornelles Morgental, Avenida lpiranga 6681, Prédio 6, 90619-900 Porto Alegre, RS, Brasil. Tel: +55-51-3320-3562. e-mail: remorgental@hotmail.com

\section{Introduction}

Root canal instrumentation comprises the combined action of endodontic instruments and irrigating solutions, with the objective of eliminating the microbial content and its byproducts, as well as inorganic and organic remnants and debris generated during operative procedures (1). An irrigating solution should present a number of physicochemical and biological properties in order to be effective.

Sodium hypochlorite $(\mathrm{NaOCl})$, in concentrations ranging from $0.5 \%$ to $6 \%$, is the most widely used irrigating solution in endodontics (2). However, despite its excellent antimicrobial potential and ability to dissolve organic tissues (3), it is only ineffective in removing the smear layer (4). For this reason, $\mathrm{NaOCl}$ is usually used in combination with a chelating agent such as EDTA (5). The demineralizing activity of this substance can be observed in root dentin because of the exposure of collagen and decrease in surface microhardness, which facilitates the action of endodontic instruments, especially in narrow root canals. In addition, smear layer removal increases dentin permeability, which may improve the penetration of irrigating solutions into the dentinal tubules, allowing greater root canal disinfection (4).

In vitro studies have shown that the higher the concentration of $\mathrm{NaOCl}$ and its time of use, the greater its influence on dentin microhardness, especially close to the root canal lumen $(2,6)$. Furthermore, chelating solutions such as EDTA, citric acid and combinations containing EDTA also promote a reduction of microhardness on the most superficial layer of dentin (4).

Due to the limitations of $\mathrm{NaOCl}$, such as its potential cytotoxic and caustic effects on periapical tissues (3), and its deleterious effect on dentin elastic modulus and flexural strength (7), some alternatives to this solution have been studied. The aim is to obtain an irrigant with equivalent antimicrobial properties, gentle effect on vital tissues and able of removing debris from dentin surfaces without unduly weakening the dental structure.

Recent literature has been suggesting the use of irrigants known as "electrochemically activated water" (ECA) (8), "oxidative potential water" (9) or even "superoxidized water" (10). These solutions are typically obtained by electrolysis of a saline solution, in a process similar to the one used for the commercial production of $\mathrm{NaOCl}$. 
The endodontic literature on the subject is still scarce, but reveals a promising future. The solutions obtained by that process have been tested for their ability to remove debris and smear layer from root canals (11), eliminate bacteria $(8,10)$ and also for their cytotoxic effects $(9)$.

Investigations have evaluated the effectiveness of these solutions in removing Enterococcus faecalis biofilms with diverging results. Some studies have demonstrated greater efficacy of $\mathrm{NaOCl}$ in comparison to super-oxidized waters $(8,10)$ while others suggest equivalent disinfecting ability for those solutions (12).

Sterilox, a commercially available super-oxidized water, has been evaluated for its capacity of disinfecting endoscopes (13). The authors found high effectiveness in eliminating spores, mycobacteria, fungi and a variety of other microorganisms, when used within 24 hours after its preparation. Although Sterilox ${ }^{\circledR}$ solution has emerged as an alternative irrigant in endodontics, so far, its effect on dentin microhardness is still unknown. Information about such effect is critical since an improper irrigation protocol, capable of weakening the dental structure in depth, may affect its strength and increase the probability of fracture.

Thus, this study aimed to evaluate the effect of Sterilox (a hypochlorous acid-containing superoxidized water) and two concentrations of sodium hypochlorite, associated or not with EDTA, on bovine dentin microhardness, considering the inner layer of dentin (close to the root canal lumen), compared to the outer layer of dentin (close to the root surface).

\section{Material and Methods}

\section{Experimental Groups Distribution}

Eighty bovine incisors were selected, with standardized lengths of $20 \mathrm{~mm}$, after previous removal of the cervical portions. The periodontal ligament was scraped off with curettes and the pulp was extirpated. Teeth were stored in distilled water until use and divided into eight groups $(n=10)$, using random allocation with stratification by the initial instrument (sizes 40,50 and 60 ). The following groups were established, according to the irrigating solution used during chemomechanical preparation of the root canal: $2 \% \mathrm{NaOCl}(2 \mathrm{NaOCl}), 5 \%$ $\mathrm{NaOCl}(5 \mathrm{NaOCl}), 400 \mathrm{ppm}$ Sterilox (Sx) and 17\% EDTA (E) used individually; $2 \% \mathrm{NaOCl}$ and 17\% EDTA (2NaOCl+E); $5 \% \mathrm{NaOCl}$ and $17 \%$ EDTA $(5 \mathrm{NaOCl}+\mathrm{E}) ; 400 \mathrm{ppm}$ Sterilox and 17\% EDTA (Sx+E) (groups associated with final irrigation of EDTA for $5 \mathrm{~min})$; and distilled water $\left(\mathrm{dH}_{2} \mathrm{O}\right)$ - negative control. $\mathrm{NaOCl}$ concentration was determined by iodometric titration, while EDTA concentration was established by volumetric analysis.

$\mathrm{NaOCl}$ and EDTA solutions were prepared (CIENTEC
- Science and Technology Foundation, Porto Alegre, RS, Brazil) seven days prior to use and stored in the dark at room temperature. Also, $400 \mathrm{ppm}$ Sterilox solution (Optident Dental, Ilkley, West Yorkshire, UK) was obtained about fifteen minutes before use by a double passage of a sodium chloride solution (Optident Sterilox Electrolyte Solution, Optident Dental) into titanium electrodes, using the Sterilox Dental System (Optident Dental).

\section{Chemomechanical Preparation of the Root Canals}

All root canals were prepared by a single and calibrated operator, attaching the specimens in a fixing device (NBLBC; Neboluz, São Paulo, SP, Brazil). The root apices were previously sealed with utility wax. The root canals were initially irrigated with $2 \mathrm{~mL}$ of the corresponding irrigating solution, and then explored with a size \#35 K-file (Dentsply-Maillefer, Ballaigues, Switzerland). The endodontic instrument was introduced into the root canal until its tip was visible at the apical foramen. The working length (WL) was established at $19 \mathrm{~mm}$; i.e., $1 \mathrm{~mm}$ from the total canal length.

Irrigating solutions were delivered by using Endo-Eze 30G needles (Ultradent Products Inc., South Jordan, UT, USA) attached to $10 \mathrm{~mL}$ disposable plastic syringes (BD Becton Dickinson, São Paulo, SP, Brazil). Simultaneously, suction was performed with the aid of a \#20 cannula (Indusbello, Londina, PR, Brazil) adapted to the root canal entrance.

All root canals were instrumented by the classic technique and the first instrument was the one that fitted the canal walls at full WL (sizes 40,50 or 60 ). The last instrument used was a size $80 \mathrm{~K}$-file. At each instrument change, irrigation/suction were carried out, with $2 \mathrm{~mL}$ of the corresponding solution, by back and forth movements. Needle penetration reached up to $3 \mathrm{~mm}$ short of the WL, thus allowing space for solution reflux.

Total irrigation time was standardized at $30 \mathrm{~min}$ per specimen. In the groups with final irrigation $(2 \mathrm{NaOCl}+\mathrm{E}$, $5 \mathrm{NaOCl}+\mathrm{E}$ and $\mathrm{Sx}+\mathrm{E}), 2 \mathrm{~mL}$ of EDTA were used and remained for extra $5 \mathrm{~min}$ in the root canal. At the end, $2 \mathrm{~mL}$ of $\mathrm{NaOCl}$ or $\mathrm{Sx}$ were employed. All canals were dried with size 80 absorbent paper points (Tanari; Tanariman Industrial Ltda, Manacapuru, AM, Brazil).

\section{Dentin Microhardness Measurements}

After chemomechanical preparation, the cervical 5 $\mathrm{mm}$ of each sample were sectioned perpendicular to its long axis and embedded in acrylic resin (JET, São Paulo, SP, Brazil), except for the cervical surface, which was submitted to polishing with 400-, 600- and 1200-grit silicon carbide papers (3M ESPE, St. Paul, MN) in order to obtain a smooth surface without gradients. The specimens were finished 
with felt discs impregnated with diamond paste (Buehler, Lake Bluff, IL, USA) and washed in running water.

Afterwards, the specimens were positioned in a Microhardness Tester (HMV-G; Shimadzu Corp., Tokyo, Japan) and measurements were taken in Vickers hardness units (VHN). Two indentations were made, under 300-g load and 10-s dwell time, perpendicular to the indentation surface. The first indentation was performed at approximately 500-1000 $\mu \mathrm{m}$ from the root canal lumen (distance 1) and the other at approximately 500-1000 $\mu \mathrm{m}$ from the outside surface of the root (distance 2).

\section{Statistical Analysis}

Data were analyzed by Wilcoxon's test for comparing distance 1 and 2 in each group. Moreover, Kruskal-Wallis's test, followed by Dunn's test, was applied for the comparison among groups at each distance. A significance level of $5 \%$ was set for all analyses.

\section{Results}

Vickers microhardness values (mean and standard deviation) for each irrigation protocol are shown in Table 1. Values at distance 1 were significantly lower than $\therefore$ those at distance 2 for all groups, except $5 \mathrm{NaOCl}$ and $5 \mathrm{NaOCl}+\mathrm{E}(\mathrm{p}>0.05)$. EDTA showed the lowest microhardness values. However, no statistically significant difference was detected among groups at distance 1 and EDTA was significantly different only from Sx at distance 2 .

\section{Discussion}

The use of auxiliary chemical substances during root canal preparation, associated with the mechanical action of endodontic instruments, is of paramount importance for infection control in the root canal system (10). However, the substances used in clinical practice may

Table 1. Vickers microhardness values (mean \pm standard deviation) of root canal dentin after different irrigation protocols

\begin{tabular}{lcc}
\hline Irrigants & $\begin{array}{c}\text { Distance } 1 \\
\text { (Internal layer) }\end{array}$ & $\begin{array}{c}\text { Distance } 2 \\
\text { (External layer) }\end{array}$ \\
\hline $5 \mathrm{NaOCl}$ & $197.29 \pm 73.49 \mathrm{~A} \mathrm{a}$ & $237.90 \pm 83.79 \mathrm{~A} \mathrm{ab}$ \\
$5 \mathrm{NaOCl}+\mathrm{E}$ & $219.10 \pm 71.59 \mathrm{~A} \mathrm{a}$ & $327.20 \pm 163.72 \mathrm{~A} \mathrm{ab}$ \\
$2 \mathrm{NaOCl}$ & $224.20 \pm 100.68 \mathrm{~A} \mathrm{a}$ & $273.10 \pm 109.57 \mathrm{~B} \mathrm{ab}$ \\
$2 \mathrm{NaOCl}+\mathrm{E}$ & $189.84 \pm 72.47 \mathrm{~A} \mathrm{a}$ & $286.70 \pm 63.26 \mathrm{~B} \mathrm{ab}$ \\
$\mathrm{Sx}$ & $197.20 \pm 66.91 \mathrm{~A} \mathrm{a}$ & $339.70 \pm 85.18 \mathrm{~B} \mathrm{a}$ \\
$\mathrm{Sx}+\mathrm{E}$ & $170.13 \pm 50.76 \mathrm{~A} \mathrm{a}$ & $267.70 \pm 56.72 \mathrm{~B} \mathrm{ab}$ \\
$\mathrm{E}$ & $156.70 \pm 24.24 \mathrm{~A} \mathrm{a}$ & $212.90 \pm 41.23 \mathrm{~B} \mathrm{~b}$ \\
$\mathrm{dH} 20$ & $189.50 \pm 54.11 \mathrm{~A} \mathrm{a}$ & $242.10 \pm 50.12 \mathrm{~B} \mathrm{ab}$ \\
\hline
\end{tabular}

Different upper letters indicate statistically significant difference $(p<0.05)$ between distance 1 and 2 . Different lower letters indicate statistically significant difference $(p<0.05)$ between groups in the same distance. induce considerable changes in dentin surface morphology, which may cause changes in its physical and mechanical properties (14). Some substances modify the inorganic component of dentin and consequently its hardness (6). Panighi and G'Sell (15) found a positive correlation between the mineral component of dentin and its hardness. Accordingly, the determination of hardness may provide important evidence about the effects of irrigating solutions on dentin and consequently on its resistance to fracture.

The present study investigated the effect of $\mathrm{NaOCl}$ and Sterilox on root dentin microhardness combined or not with EDTA. Two indentation methods, Knoop and Vickers, were used to evaluate this property (16). Irrigants are usually compared to distilled water (18), saline (2) or no irrigation (4), as the negative control. Although some studies have suggested lower sensitivity of Vickers microhardness to surface conditions (16), this method has support in the literature $(2,17,18)$ when the aim is to compare the reduction of dentin microhardness in superficial and deep areas. For this reason, it was chosen for this study, using a $300-\mathrm{g}$ load for $10 \mathrm{~s}$, as previously described $(2,17,18)$.

Microhardness values at distance 1 , close to the root canals walls, were significantly lower than the values obtained at distance 2 for all groups, except $5 \mathrm{NaOCl}$ and $5 \mathrm{NaOCl}+\mathrm{E}(\mathrm{p}>0.05)$. This finding was expected since lower microhardness measurements near the root canal lumen have already been reported in the literature in connection with greater dentinal tubule density $(19,20)$. The lack of significant difference between those two distances in groups $5 \mathrm{NaOCl}$ and $5 \mathrm{NaOCl}+\mathrm{E}$ indicates that this solution acts in deeper areas. This fact may be explained by the collagen degradation promoted by concentrated $\mathrm{NaOCl}$. The deterioration of the organic component of dentin, formed mainly by collagen, causes mechanical changes in its structure (7) and occurs after the first $10 \mathrm{~min}$ of contact between the solution and the dentin walls (2).

The application of chelating agents such as EDTA is suggested to assist root canal preparation, since they act on the inorganic component of dentin and potentially reduce dentin microhardness $(4,21)$, facilitating the action of endodontic cutting instruments. In the present investigation, when used individually, EDTA showed the lowest microhardness values, but statistically significant difference was detected only in comparison to the Sterilox group at distance 2. Therefore, it is considered that Sterilox solution acts superficially on organic matter and can hardly cause changes in the dentin layer close to the root surface. Furthermore, the contact time between EDTA and dentin in this study $(30 \mathrm{~min})$ was higher than the usual final irrigation regimen ( $5 \mathrm{~min}$ ), which may also have caused greater changes in depth. 
Due to the increasing difficulty of obtaining human teeth, bovine incisors were used as an alternative. This experimental model allows also better standardization. It was possible to obtain samples of similar donor age and dentin characteristics, thereby allowing the distribution of teeth from the same animal into several groups. Moreover, studies have shown similarities between these two models; bovine dentin has higher number of dentinal tubules but with equivalent diameters (22).

The number and diameter of dentinal tubules are crucial for the penetration and subsequent effects of therapeutic agents directly applied on dentin (22). According to Pashley et al. (20), there is an inverse correlation between dentin hardness and dentinal tubules density. Since a greater density of tubules occurs near the root canal lumen, the lower resistance in that region is attributed to this fact. A lower hardness of human dentin in the cementum-dentin junction and near the root canal walls was first suggested by Patterson (23).

Burrow et al. (19) assessed the influence of age and depth of dentin on the tensile bond strength of different bonding systems. In their study, the important information with respect to dentin microhardness is the fact that hydraulic conductance is higher in young dentin. This feature, besides tubules density and diameter, may affect the penetration of irrigating solutions and, consequently, decrease the influence of the solution on the dentin microhardness in depth. According to Barbosa et al. (24), the hydraulic conductance of dentin increases over $100 \%$ after treatment with $5 \% \mathrm{NaOCl}$, which suggests a negative effect of high concentrations of this substance on the integrity of the root canal walls.

Based on a previous study (18), in which the authors suggest a crucial effect of the irrigation period on dentin microhardness, was standardized the time of irrigation combined with mechanical preparation at $30 \mathrm{~min}$. It was tried to simulate the clinical condition in contrast to the research of Ari et al. (17), who dived the dentin samples in the tested solutions for $15 \mathrm{~min}$, or the investigation of Cruz-Filho et al. (4) who delivered the irrigating solution directly onto previously sectioned dentin samples with the aid of micropipettes. These alternative forms of contact between solutions and dentin may explain the slightly different results from those obtained in the present study, but with the same tendency. Microhardness values found in this study were higher in comparison to the effect found in their work. Herein, EDTA and $\mathrm{NaOCl}$ presented microhardness values similar to distilled water, which is a positive finding from a clinical standpoint.

Although the reduction in dentin microhardness close to the root canal is a desirable effect (4), mainly provided by chelating agents, it is necessary to prevent a prolonged permanence of EDTA in contact with the root canal walls and use of $\mathrm{NaOCl}$ solutions in high concentrations, due to the risk of causing relevant mechanical changes in dental structure and decreasing the resistance of teeth until fracture as a result. Also, the erosion effect promoted by prolonged permanence of EDTA must be considered, especially when used in association to $\mathrm{NaOCl}$. The erosion promotes morphological alteration in root dentin, which may potentially interfere on the adhesion of endodontic sealers (25).

On the basis of the results obtained and the experimental conditions of the present study, it was concluded that after using the irrigating solutions, with the exception of $5 \% \mathrm{NaOCl}$, associated or not with EDTA, dentin microhardness close to the root canal lumen was significantly lower than the one near the external root surface. Also, EDTA promoted lower microhardness values in comparison to Sterilox ${ }^{\circledR}$ on the external layer of dentin.

\section{Resumo}

0 presente estudo teve como objetivo avaliar a influência das seguintes soluções irrigadoras na microdureza da dentina do canal radicular: hipoclorito de sódio a $2 \%(\mathrm{NaOCl})$, hipoclorito de sódio a $5 \%(\mathrm{NaOCl})$, água superoxidada (Sterilox 400 ppm - Sx) e EDTA a 17\% (E). Oitenta raizes de incisivos bovinos foram divididas aleatoriamente em 8 grupos ( $n=10): \mathrm{NaOCl}$, NaOCl5, Sx e NaOCl2 $+\mathrm{E}_{1} \mathrm{NaOCl} 5+\mathrm{E}_{1} \mathrm{Sx}+\mathrm{E}$ (associados ao $\mathrm{E}$ como irrigante final por $5 \mathrm{~min}$ ), $\mathrm{E}$ isolado e água destilada ( $\mathrm{H} 2 \mathrm{Od}$ ), como controle negativo. 0 preparo dos canais radiculares foi realizado com instrumentos manuais, usando um dos protocolos de irrigação por $30 \mathrm{~min}$. A seguir, $5 \mathrm{~mm}$ do terço cervical de cada amostra foram cortados perpendicularmente e submetidos ao teste de microdureza de Vickers, em dois pontos, um aproximadamente $500-1000 \mu \mathrm{m}$ da luz do canal radicular (distância 1), e o outro aproximadamente 500-1000 $\mu \mathrm{m}$ da superfície externa da raiz (distância 2). Os dados foram analisados pelos testes de Wilcoxon e Kruskal-Wallis com um nivel de significância de 5\%. Os valores de microdureza na distância 1 foram significativamente menores do que na distância 2 para todos os grupos, exceto $\mathrm{NaOCl} 5$ e $\mathrm{NaOCl} 5+\mathrm{E}$ $(p>0,05)$. O EDTA mostrou os menores valores de microdureza. No entanto, não foi detectada diferença estatisticamente significativa entre os grupos na distância 1 e o EDTA foi significativamente diferente apenas do Sx na distância 2. Pode-se concluir que todas as soluções testadas mostraram menor microdureza na camada de dentina mais superficial do canal radicular em comparação aos valores encontrados próximo à superfície radicular externa, exceto $\mathrm{NaOCl} 5$ e $\mathrm{NaOCl}_{\circledast}+\mathrm{E}_{\text {; }}$ o EDTA promoveu menor microdureza em comparação ao Sterilox neste ponto.

\section{References}

1. Hulsmann $M$, Heckendorff $M$, Lennon A. Chelating agents in root canal treatment: mode of action and indications for their use. Int Endod J 2003;36:810-830.

2. Slutzky-Goldberg I, Maree M, Liberman R, Heling I. Effect of sodium hypochlorite on dentin microhardness. J Endod 2004;30:880-882.

3. Mohammadi Z. Sodium hypochlorite in endodontics: an update review. Int Dent J 2008;58:329-341.

4. Cruz-Filho AM, Sousa-Neto MD, Savioli RN, Silva RG, Vansan LP, Pecora JD. Effect of chelating solutions on the microhardness of root canal lumen dentin. J Endod 2011;37:358-362.

5. Baumgartner JC, Mader CL. A scanning electron microscopic evaluation of four root canal irrigation regimens. J Endod 1987;13:147-157.

6. Van Meerbeek B, Willems G, Celis JP, Roos JR, Braem M, Lambrechts P 
et al.. Assessment by nano-indentation of the hardness and elasticity of the resin-dentin bonding area. J Dent Res 1993;72:1434-1442.

7. Grigoratos D, Knowles J, Ng YL, Gulabivala K. Effect of exposing dentine to sodium hypochlorite and calcium hydroxide on its flexural strength and elastic modulus. Int Endod J 2001;34:113-119.

8. Gulabivala K, Stock CJ, Lewsey JD, Ghori S, Ng YL, Spratt DA. Effectiveness of electrochemically activated water as an irrigant in an infected tooth model. Int Endod J 2004;37:624-631.

9. Serper A, Calt S, Dogan AL, Guc D, Ozcelik B, Kuraner T. Comparison of the cytotoxic effects and smear layer removing capacity of oxidative potential water, $\mathrm{NaOCl}$ and EDTA. J Oral Sci 2001;43:233-238.

10. Rossi-Fedele G, Figueiredo JA, Steier L, Canullo L, Steier G, Roberts AP. Evaluation of the antimicrobial effect of super-oxidized water (Sterilox ${ }^{\circledR}$ ) and sodium hypochlorite against Enterococcus faecalis in a bovine root canal model. J Appl Oral Sci 2010;18:498-502.

11. Garcia F, Murray PE, Garcia-Godoy F, Namerow KN. Effect of Aquatine Endodontic Cleanser on smear layer removal in the root canals of ex vivo human teeth. J Appl Oral Sci 2010;18:403-408.

12. Marais JT. Investigations into the application of electrochemically activated water in dentistry. SADJ 2000;55:381-386.

13. Shetty N, Srinivasan S, Holton J, Ridgway GL. Evaluation of microbicidal activity of a new disinfectant: Sterilox 2500 against Clostridium difficile spores, Helicobacter pylori, vancomycin resistant Enterococcus species, Candida albicans and several Mycobacterium species. J Hosp Infect 1999;41:101-105.

14. Pascon FM, Kantovitz KR, Sacramento PA, Nobre-dos-Santos M, Puppin-Rontani RM. Effect of sodium hypochlorite on dentine mechanical properties. A review. J Dent 2009;37:903-908.

15. Panighi M, G'Sell C. Effect of the tooth microstructure on the shear bond strength of a dental composite. J Biomed Mater Res 1993;27:975981.
17. Ari $H$, Erdemir A, Belli S. Evaluation of the effect of endodontic irrigation solutions on the microhardness and the roughness of root canal dentin. J Endod 2004;30:792-795.

18. Slutzky-Goldberg I, Liberman R, Heling I. The effect of instrumentation with two different file types, each with $2.5 \% \mathrm{NaOCl}$ irrigation on the microhardness of root dentin. J Endod 2002;28:311-312

19. Burrow MF, Takakura H, Nakajima M, Inai N, Tagami J, Takatsu T. The influence of age and depth of dentin on bonding. Dent Mater 1994;10:241-246.

20. Pashley D, Okabe A, Parham P. The relationship between dentin microhardness and tubule density. Endod Dent Traumatol 1985;1:176179.

21. Saleh AA, Ettman WM. Effect of endodontic irrigation solutions on microhardness of root canal dentine. J Dent 1999;27:43-46.

22. Camargo $\mathrm{CH}$, Siviero $\mathrm{M}$, Camargo $\mathrm{SE}$, de Oliveira $\mathrm{SH}$, Carvalho $\mathrm{CA}$, Valera MC. Topographical, diametral and quantitative analysis of dentin tubules in the root canals of human and bovine teeth. J Endod 2007;33:422-426.

23. Patterson SS. In vivo and in vitro studies of the effect of the disodium slat of ethylenediamine tetra-acetate on human dentine and its endodontic implications. Oral Surg Oral Med Oral Pathol 1963;16:83103.

24. Barbosa SV, Safavi KE, Spangberg SW. Influence of sodium hypochlorite on the permeability and structure of cervical human dentine. Int Endod J 1994;27:309-312.

25. Aranda-Garcia AJ, Kuga MC, Chavéz-Andrade GM, Kalatzis-Sousa NG, Hungaro Duarte MA, Faria G, et al.. Effect of final irrigation protocols on microhardness and erosion of root canal dentin. Microsc Res Tech 2013;76:1079-1083. 